\title{
Analisis Kekerasan Simbolik dalam Buku Pelajaran Pendidikan Agama Islam di Sekolah Dasar
}

\author{
Nur Ika Fatmawati \\ Universitas Islam Negeri Sunan Kalijaga Yogyakarta \\ Email: fatmanaura.ahmad@gmail.com \\ Aninditya Sri Nugraheni \\ Universitas Islam Negeri Sunan Kalijaga Yogyakarta \\ Email: anin.suka@gmail.com
}

\author{
Ahmad Sholikin \\ Universitas Islam Darul Ulum \\ Email: akhmad.sholikin@gmail.com
}

\begin{abstract}
This research explains about symbolic violence in Islamic religious education books is rarely done. It also checks whether or not the books used so far contain symbolic violence, because there should be no difference in religious education between upper-class and lower-class. The formulation of the problems in this study are; how the mechanism of symbolic violence in Islamic religious education textbooks in elementary schools, and how the proportion of upper-class habitus and lower-class habitus in Islamic religious education textbooks in elementary schools. This research is a qualitative study with the type of literature study. The results showed that symbolic violence still occurred in elementary schools. The mechanism that runs is through an educational strategy by hiding the process of symbolic violence in the curriculum or what we know as the hidden curriculum. One of the media used to perpetrate violence is a textbook. In Islamic Religious Education textbooks for elementary school level), there is an element of upper-class domination over the lower class. The dominance of the upper-class over the lower-classes can be seen from the proportion of habitus presented in the textbook, the number of upper-class habitus presented through sentences and pictures illustrated is far higher than the lower-class habitus.
\end{abstract}

Keywords: symbolic violence, textbooks, Islamic religious education

\begin{abstract}
Abstrak
Penelitian ini menjelaskan tentang kekerasan simbolik pada buku-buku Pendidikan Agama Islam masih jarang dilakukan. Ini juga menganalisis apakah dalam buku yang digunakan sejauh ini mengandung kekerasan simbolik atau tidak, karena seharusnya tidak ada perbedaan dalam pendidikan agama antara kelas atas dan kelas bawah. Rumusan masalah dalam penelitian ini adalah bagaimana mekanisme kekerasan simbolik dalam buku teks Pendidikan Agama Islam di Sekolah Dasar, dan bagaimana proporsi habitus kelas atas dan habitus kelas bawah dalam buku teks Pendidikan Agama Islam di Sekolah Dasar. Penelitian ini adalah penelitian kualitatif dengan jenis studi literatur. Hasil penelitian menunjukkan bahwa kekerasan simbolik masih terjadi di Sekolah Dasar. Mekanisme yang berjalan adalah melalui strategi pendidikan dengan menyembunyikan proses kekerasan simbolik dalam kurikulum atau yang kita kenal dengan istilah hidden curriculum. Salah satu media yang digunakan untuk melanggengkan kekerasan adalah buku teks. Dalam buku teks Pendidikan Agama Islam untuk tingkat Sekolah Dasar, ada unsur dominasi kelas atas terhadap kelas bawah. Dominasi kelas atas terhadap kelas bawah dapat dilihat dari proporsi habitus yang disajikan dalam buku teks, jumlah habitus kelas atas yang disajikan melalui kalimat dan gambar yang diilustrasikan jauh lebih besar daripada habitus kelas bawah.
\end{abstract}

Kata kunci: kekerasan simbolik, buku pelajaran, Pendidikan Agama Islam 


\section{A. Pendahuluan}

Pendidikan merupakan hak setiap warga Negara, setiap orang tua murid pasti mengharapkan anaknya mendapatkan pendidikan di sekolah yang terbaik, baik fasilitas maupun kualitas dan pelayanan dari guru-gurunya. Sedangkan peserta didik mengharapkan mereka merasa aman dan nyaman selama menempuh pendidikan di sekolah. Pendidikan merupakan proses dimana suatu bangsa mempersiapkan generasi mudanya untuk memenuhi tujuan hidup secara efektif dan efisien. ${ }^{1}$ Dalam Rencana Strategis Kementerian Pendidikan dan Kebudayaan salah satu tujuan yang ditetapkan adalah mewujudkan ekosistem pendidikan yang kondusif. ${ }^{2}$ Ekosistem pendidikan yang dimaksud adalah meliputi interaksi seluruh warga sekolah dan juga dengan alam atau lingkungan yang ada di dalam sekolah. Sekolah yang memiliki lingkungan atau ekosistem kondusif dapat dipahami sebagai sekolah yang di dalamnya terdapat hubungan saling ketergantungan antara manusia dengan sesamanya dan antara manusia dengan lingkungannya.

Meski demikian, isu kekerasan dalam dunia pendidikan masih tetap menarik dan penting karena kekerasan merupakan fenomena kehidupan yang selalu hadir berhadapan dengan kedamaian sepanjang sejarah kehidupan manusia. Hal ini tentu saja tidak dapat dilepaskan dari mana pun individu dalam memandu atau mengelola tiga unsur atau substansi yang melekat pada diri manusia yaitu akal, hati dan nafsu. Dalam konteks pendidikan, tindak kekerasan akan memberi dampak terhadap mutu pendidikan. Lingkungan sekolah yang didominasi kekerasan akan mempengaruhi mutu pendidikan yang diterima peserta didik. Anak-anak yang menjadi korban kekerasan akan secara sosial merasa terisolasi, tertekan (depresi) dan kurang atau lemah motivasi belajar (akademik). Keadaan ini akan mempengaruhi keseluruhan peserta didik. Bahkan temuan studi sebelumnya menunjukkan bahwa, ada hubungan antara perilaku bully dengan merosotnya prestasi siswa. ${ }^{3}$

Institusi pendidikan di Indonesia juga terdapat fakta terkait adanya bentuk kekuasaan yang timpang serta terjadi hegemoni antara pihak yang satu dalam memandang pihak lainnya. Pandangan merasa dirinya lebih superior dalam hal moral, etika, agama, jenis kelamin dan usia merupakan hal yang biasa terjadi dalam dunia pendidikan kita. Keadaan ini adalah salah satu bukti nyata dari bekerjanya pola kekerasan simbolik dan akan berdampak pada munculnya bentuk kekerasan yang nyata. ${ }^{4}$ Kekerasan yang nyata tersebut bisa berupa kekerasan ekonomi, sosial, fisik dan psikis. Sehingga kekerasan simbolik telah mengakar kuat dalam sistem pendidikan dan dalam berbagai aspek kehidupan manusia yang mengakibatkan pola relasi yang timpang antara manusia satu dan yang lainnya. Pada setiap bentuk interaksi dan relasi sosial yang timpang maka dapat dipastikan bahwa sedang berlangsung kekerasan simbolik, seperti: dalam kehidupan keluarga, pendidikan, sosial politik, ekonomi, kesehatan, bahkan dalam ranah praktik kehidupan beragama kita tidak pernah luput dari kekerasan simbolik.

Dalam konteks pendidikan, tindak kekerasan akan memberi dampak terhadap mutu pendidikan. Lingkungan sekolah yang didominasi kekerasan akan mempengaruhi mutu pendidikan yang diterima peserta didik. Anak-anak yang menjadi korban kekerasan akan secara sosial merasa terisolasi, tertekan (depresi) dan kurang atau lemah motivasi belajar.

\footnotetext{
${ }^{1}$ Azyumardi Azra, Paradigma Baru pendidikan Nasional Rekonstruksi dan Demokrasi (Jakarta: Kompas Media Nusantara, 2002), hlm. ix.

${ }^{2}$ Rencana Strategis Kementrian Pendidikan dan kebudayaan tahun 2015-2019. Diakses pada tanggal 28 Desember 2019.

${ }^{3}$ I Wahyu Sulistya Affarah, dkk. Public Sharing on Prevention and Impact of Bullying in Adolescents. Prosiding PEPADU, e-ISSN: 2715-5811 Vol. 1, 2019, Seminar Nasional Pengabdian kepada Masyarakat LPPM Universitas Mataram, hlm. 34.

${ }^{4}$ Ahmad Sholikin, Pemikiran Politik Negara dan Agama "Ahmad Syafii Maarif”. Universitas Airlangga, 2013.
} 
Keadaan ini akan mempengaruhi keseluruhan peserta didik. Kekerasan merupakan perilaku agresif yang tujuannya menyakiti fisik atau psikologis orang lain. Ia merupakan tindakan yang sengaja dilakukan untuk menyakiti seseorang. Kekerasan terjadi manakala seseorang memaksakan atau mengancam yang membuat perasaan atau fisik orang lain terluka atau sakit, dan bahkan kekayaannya hilang. Kekerasan juga merupakan fenomena kehidupan yang mewarnai hampir seluruh aspek kehidupan sosial, politik dan budaya, rumah tangga dan bahkan pendidikan. ${ }^{5}$ Kekerasan acapkali merupakan jalan pintas dalam menyelesaikan persoalan yang dihadapi dalam kehidupan sosial, politik, budaya, pendidikan, seperti kasuskasus konflik dalam Pilkada, sidang di DPR, kegiatan siswa dan mahasiswa pada awal akademik (masa orientasi) atau dalam rumah tangga (KDRT). ${ }^{6}$

Dari beberapa literatur, kekerasan yang dilakukan dapat mengambil berbagai wujud atau jenis yaitu: (a) Kekerasan Mental yaitu pemikiran menyakiti orang lain atau menuduh orang lain salah atau sesat (tanpa dasar). (b) Kekerasan verbal atau ujar, yaitu menggunakan kata-kata tidak simpatik atau jijik menyakitkan orang lain. (c) Kekerasan fisik yaitu menggunakan kekuatan fisik untuk menyakiti orang lain, individu, kelompok, masyarakat, negara. $^{7}$ (d) Kekerasan struktural adalah ketidakadilan seperti kemiskinan, diskriminasi dan akses yang tidak adil untuk mendapat kesempatan, dan ketidakadilan menjadi akar atau penyebab konflik. (e) Kekerasan simbolik yaitu imposisi atau memaksa memberlakukan sistem simbol dan arti (budaya) kelompok atau kelas atas dengan cara perlahan/tidak tampak/ halus sehingga mereka (yang menjadi sasaran) merasakan atau mengakuinya sebagai sesuatu yang absah, untuk kepentingan kelompok yang mendominasi. ${ }^{8}$

Pola relasi dan interaksi yang terjadi secara keseluruhan akan memiliki potensi untuk melahirkan dan mengakibatkan perilaku kekerasan yang nyata. Karena kekerasan simbolik beroperasi di bawah ketidaksadaran pelaku dan korbannya sehingga bersifat nir-sadar dan laten. Ketika hal itu terjadi maka kekerasan simbolik tidak akan dapat dengan mudah dikenali bentuk kekerasannya dan tidak dirasakan sebagai bentuk kekerasan oleh pihak yang menjadi sasaran kekerasan. ${ }^{9}$ Dengan pola operasi yang tersembunyi tersebut, maka kekerasan simbolik dapat diterima oleh pihak yang menjadi sasaran kekerasan sebagai bentuk hal yang wajar. ${ }^{10}$ Praktik kekerasan simbolik dapat dilakukan dengan dua cara. Pertama dengan mekanisme yang disebut dengan eufimisme. Eufimisme adalah mekanisme kekerasan simbolik dengan mengondisikan kekerasan simbolik menjadi tidak tampak, bekerja secara halus, tidak dapat dikenali, serta dapat dipilih secara "tidak sadar". ${ }^{11}$ Bentuk eufimisme yang sering terjadi berupa kepercayaan, kewajiban, kesetiaan, sopan santun, pemberian, utang, pahala, dan belas kasihan. Kedua, kekerasan simbolik dijalankan dengan mekanisme yang disebut dengan sensorisasi yaitu mekanisme dengan menjadikan kekerasan simbolik terlihat sebagai bentuk sebuah pelestarian segala bentuk nilai yang dianggap sebagai "moral kehormatan", antara lain seperti: kesantunan, kesucian, kedermawanan, dan lain sebagainya yang biasanya dipertentangkan dengan apa yang disebut dengan "moral rendah" antara lain seperti: kekerasan, kriminal, ketidakpantasan, asusila, kerakusan, dan lain sebagainya. Bahkan

\footnotetext{
${ }^{5}$ Ahmad Solikhin, Islam, Negara, dan Perlindungan Hak-Hak Islam Minoritas. Journal of Governance, 1(1) 2016.

${ }^{6}$ Nanang Martono, Kekerasan Simbolik di Sekolah (Sebuah Ide Sosiologi Pendidikan Pierre Bourdieu (Jakarta: Raja Grafindo, 2012), hlm. 14. hlm. 56.

${ }^{7}$ Marmar Mukhopadhyay, Peace Education Framework for Teacher Education (India: UNICEF, 2005),

${ }^{8}$ Ibid, hlm. 24.

${ }^{9}$ Ibid, hlm. 4.

${ }^{10}$ Suna Riela Rusdiarti, Bahasa, Pertarungan Simbolik dan Kekuasaan. Edisi Khusus Pierre Bourdie No. 11-12 tahun ke-52, 2003, hlm. 78.

${ }^{11}$ Haryatmoko, Etika Politik dan Kekuasaan (Jakarta: Penerbit Buku Kompas, 2003), hlm. 90.
} 
terdapat beragam mekanisme eufemisasi dan sensorisasi yang direpresentasikan dalam wacana pembelajaran. ${ }^{12}$

Berdasarkan latar belakang yang telah dipaparkan di atas, maka pertanyaan pada penelitian ini adalah sebagai berikut: Bagaimana mekanisme kekerasan simbolik dalam buku pelajaran PAI di Sekolah Dasar? Bagaimana proporsi habitus kelas atas dan habitus kelas bawah dalam buku pelajaran PAI di Sekolah Dasar? Jenis penelitian yang digunakan dalam penelitian ini adalah jenis kualitatif deskriptif, yaitu pemaparan gambaran mengenai situasi yang diteliti dalam bentuk uraian naratif disertai grafik perbandingan. Data yang berupa angka kemudian dijelaskan dengan uraian naratif. Berdasarkan objek kajian, maka penelitian ini termasuk penelitian bersifat kepustakaan (Library Research). Objek dari penelitian yang penulis lakukan adalah buku pelajaran PAI yang diterbitkan oleh Kemendikbud, mulai kelas 1-6 yang menjadi salah satu media pembelajaran di Sekolah Dasar (selanjutnya disingkat SD).

Teknik pengumpulan data yang ditempuh adalah dokumentasi. Dokumentasi yang dimaksud bisa berbentuk fitur, rubrikasi, uraian materi, atau karya-karya yang dihasilkan oleh seseorang ataupun sebuah institusi yang memiliki relevansi dengan penelitian ${ }^{13}$. Selanjutnya, untuk kepentingan menganalisis data penelitian agar diperoleh hasil analisis yang lebih rinci, maka metode content analysis (analisis isi) menjadi pilihan utama penulis, karena dengan metode ini dimungkinkan bagi peneliti untuk mendapatkan muatan, isi, serta bentuk-bentuk dari kekerasan simbolik dalam setiap fitur, rubrikasi, dan uraian dalam pokok bahasan dengan mengesampingkan makna-makna simbolik yang terdapat di dalamnya. ${ }^{14}$ Metode kedua adalah interpretatif, dengan cara menyelami isi buku untuk diungkap arti serta nuansa yang disajikan. Untuk menginterpretasi kalimat atau gambar dalam buku, penelitian ini memanfaatkan metode semiotika Bourdieu.

\section{B. Temuan Data}

\section{B.1. Dominasi kelas dalam buku pelajaran PAI di SD}

Kekerasan simbolik dalam buku ajar Pendidikan Agama Islam (selanjutnya disingkat PAI) di SD ditunjukkan dengan adanya dominasi kelas terhadap kelas lain. Habitus kelas atas dan habitus kelas bawah yang ditampilkan dalam buku menjadi instrumen untuk mengetahui bagian kelas yang dominan dan kelas mana yang terdominasi. Sosialisasi habitus kelas dalam buku ajar tanpa disadari peserta didik maupun orang tua telah mempengaruhi gaya hidup dan pola pikir peserta didik. Ketidaksadaran objek sasaran inilah yang dikatakan Bourdieu sebagai proses kekerasan simbolik, pemaksaan terselubung, sangat halus dan akhirnya berpengaruh terhadap pola kehidupan. Tanpa disadari peserta didik telah menjadi korban kekerasan simbolik yang menyebabkan mereka menganggap apa yang ditampilkan secara dominan dalam buku ajar sebagai sesuatu yang baik, patut dicontoh dan diikuti, padahal habitus yang ditampilkan belum tentu baik dan sesuai realitas.

Untuk mengetahui dominasi kelas dalam buku ajar PAI di SD, maka dibuat komparasi antara habitus kelas atas dengan habitus kelas bawah yang ditunjukkan dalam bentuk kalimat, kalimat tersebut dapat berupa penjelas materi, contoh, maupun latihan -latihan yang menunjukkan bias kelas. Setelah mengidentifikasi kalimat yang mengandung dominasi kelas, selanjutnya dibuat perbandingan dominasi di antara kedua habitus. Komparasi hasil identifikasi tersebut mendapatkan data berapa besar habitus kelas atas dan kelas bawah yang ditunjukkan dalam kalimat, dari jumlah kalimat yang ada, menjelaskan kelas mana yang

\footnotetext{
${ }^{12}$ Ulfah, Kekerasan Simbolik dalam Wacana Pembelajaran, Jurnal Pendidikan Insani, vol 14, no. 1 2013, hlm. 51-58.

${ }^{13}$ Sugiono, Metode Penelitian Pendidikan: Pendekatan Kualitatif Kuantitatif dan $R \& D$ (Bandung: Alfabeta, 2006), hlm. 308-309.

${ }^{14}$ Klaous Krippendroff, Content Analysis: Introduction to its Theory and Metodology, dalam Farid Wajidi, Analisis Isi, Pengantar Teori dan Metodologi (Jakarta: Rajawali, 1991), hlm. 32.
} 
dominan dan kelas mana yang terdominasi. Dominasi inilah yang merupakan kekerasan simbolik yang terjadi di SD melalui buku ajar, yang tanpa disadari dan jelas terjadi.

Beberapa kalimat yang ada dalam buku ajar PAI di SD menunjukkan bias kelas sosial. Dari hasil penelitian didapatkan data bahwa habitus kelas atas lebih banyak dijadikan contoh. Dominasi kelas atas sebanyak 41 kalimat dari 58 kalimat yang menunjukkan bias kelas atau mencapai $71 \%$ kalimat. Sementara kalimat yang menunjukkan habitus kelas bawah hanya 17 kalimat atau sekitar 29\% dari jumlah keseluruhan.

Untuk lebih jelasnya, perbandingan kedua habitus kelas tersebut dapat dilihat pada tabel berikut ini:

Diagram 1: Dominasi Kelas Melalui Bahasa

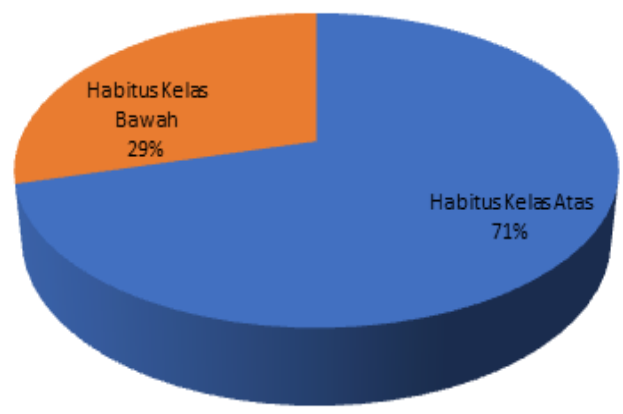

Dari hasil tersebut dapat ditarik kesimpulan bahwa habitus kelas atas jauh lebih dominan, begitu dominannya habitus kelas atas bahkan dalam pelajaran agama sekalipun. Padahal peserta didik bukan hanya berasal dari kelas atas melainkan juga dari kelas bawah.

Dominasi berupa kalimat penjelas, contoh, dan latihan-latihan menjadi jalan mensosialisasikan kebiasaan, gaya hidup, serta selera kelas atas. Peserta didik yang dari kelas atas dipaksa membaca dan memahami isi bacaan yang jauh dari realitas kehidupan mereka sehari-hari. Jika setiap hari dijejali dengan habitus kelas atas dan proses ini berjalan terusmenerus sejak kelas 1-6 SD, tentu saja semakin lama peserta didik akan dihadapkan mimpi menjadi seperti apa yang ada dalam buku ajar. Di sinilah mekanisme kekerasan simbolik berupa dominasi kelas atas terhadap kelas bawah berlangsung. Berikut penjelasan mengenai bagaimana dominasi dan sosialisasi habitus kelas atas yang ditampilkan melalui bahas yang disajikan dalam buku pelajaran PAI di SD.

\section{B.2. Habitus Kelas Dominan dalam Teks Buku Ajar \\ B.2.1. Kebiasaan kelas atas}

Antara habitus kelas atas dengan habitus kelas bawah tentu terdapat perbedaan. Kebiasaan yang dilakukan seseorang menunjukkan dari kalangan mana dia berasal. Kebiasaan yang terdapat dalam buku pelajaran PAI di SD menunjukkan hal tersebut, kebiasaan kelas atas lebih banyak dibandingkan dengan kebiasaan kelas bawah. Dominasi ini membuat peserta didik dari kelas bawah canggung dan sulit memahami ketika belajar sesuatu yang jauh berbeda dari realitas yang biasanya dikerjakan sehari - hari.

Rara dan Wati adalah dua sahabat yang tinggal dalam satu kompleks, Setiap berangkat sekolah, Rara dan Wati selalu bersama diantar ayah Rara yang sekaligus berangkat ke kantor.

PAI 6: halaman 83

\section{Data 1}

Kutipan teks satu menunjukkan kelas atas, hal ini bisa dilihat dari tempat tinggal di dalam kompleks, dan ayah berangkat ke kantor, kalimat tersebut digunakan untuk 
menjelaskan materi tentang "hidup rukun". Kebiasaan kelas atas yang digambarkan dari teks di atas yaitu: "Rara dan Wati adalah dua sahabat yang tinggal dalam satu kompleks. Setiap berangkat sekolah, Rara dan Wati selalu bersama diantar ayah Rara yang sekaligus berangkat ke kantor." Dari banyaknya contoh yang bisa digunakan kenapa habitus kelas atas yang ditampilkan, tentu saja kelas ataslah yang bisa menikmati tinggal di kompleks perumahan karena mereka memiliki modal ekonomi, sedangkan kebiasaan berangkat sekolah dengan diantar orang tuanya yang sekaligus akan berangkat bekerja ke kantor, menunjukkan kelas atas karena kantor merupakan tempat bekerja orang tua kelas atas berbeda dengan kelas bawah tentu saja orang tuanya sudah berjibaku dengan pekerjaan di sawah, menjadi buruh atau pekerja kasar sehingga anak dari kelas bawah lebih banyak berangkat sendiri dengan jalan kaki.

\section{B.2.2. Kepemilikan barang elektronik}

Barang elektronik seperti radio, televisi, pemutar VCD saat ini menjadi konsumsi publik, dimana banyak masyarakat yang memilikinya, padahal sebenarnya barang-barang tersebut bukan kebutuhan pokok yang harus dimiliki setiap orang, menonton televisi ataupun mendengarkan radio bukan hanya dilakukan kelas atas namun, harga elektronik yang mahal memungkinkan kelas atas yang bisa memilikinya oleh karena itu masuk ke habitus kelas atas. Berikut beberapa contoh kalimat yang ada dalam buku ajar PAI di SD yang memuat kekerasan simbolik berupa menonton televisi, mendengarkan radio.

Setiap hari, Maryam melatih diri di muka kaca di kamarnya. Dengan suara lantang dan fasih, Maryam berusaha latihan pidato, kadang di kamar atau kadang di ruang tamu di hadapan ibunya. Maryam tidak merasa kesulitan melafalkan ayat al-Qur'an, namun demikian gaya berpidato harus benar-benar dipelajarinya. Maryam sering merekam para ustad atau ustadzah yang berceramah di televisi. Maryam masih merasa grogi bila berpidato di depan orang banyak.

PAI 6: halaman 69

\section{Data 2}

Kutipan teks 10 digunakan untuk memperjelas materi tentang Menerima Qada' dan Qadar, dan kutipan teks 11 dan teks 12 contoh dari bab Sikap Toleran bab Senangnya Berakhlak Terpuji, namun pada kalimat tersebut mengandung kebiasaan kelas atas dengan "Maryam sering merekam para ustad atau ustadzah yang berceramah di televisi, tentu saja merekam butuh alat untuk merekam seperti HP atau alat record yang lain, dan Maryam merekam di televisi. Kemudian televisi, radio dan VCD juga menunjukkan kebiasaan kelas atas. Masyarakat luas saat ini sudah terbiasa menonton televisi dan mendengarkan radio, namun televisi, radio, VCD sebenarnya adalah kebutuhan sekunder, dimana jika tidak ada televisi masyarakat tidak akan sengsara. Kebiasaan menonton televisi merupakan habitus kelas atas karena harga TV yang lumayan mahal banyak kelas bawah yang tidak memiliki televisi sehingga harus menonton di rumah tetangga.

\section{B.2.3. Pergi bertamasya}

Bertamasya, atau piknik memang bukan hana dilakukan oleh kelas atas saja, hal itu bisa terjadi karena hampir seluruh sekolah rutin mengadakan liburan bersama ketika musim libur sekolah tiba. Mereka yang berasal dari kelas atas maupun kelas bawah memiliki kesempatan yang sama untuk bertamasya. Bertamasya jika dilakukan di luar kota tentu saja membutuhkan biaya yang tidak sedikit, banyaknya biaya yang dikeluarkan tentu saja memberatkan kelas bawah untuk ikut bertamasya, sementara kelas atas tidak akan keberatan. Misalnya wisata yang dikoordinir oleh pihak sekolah, peserta didik dari kelas bawah tentu saja jauh-jauh hari harus sudah menabung demi bisa ikut, bahkan orang tua wali murid harus 
merogoh uang lagi atau bahkan harus menghutang kepada tetangga demi memberikan uang saku kepada anaknya.

Dengan demikian berlibur atau bertamasya merupakan habitus kelas atas mengingat biaya yang dikeluarkan cukup besar. Bukan berarti kelas bawah tidak berhak bertamasya namun akses dan kesempatan untuk berlibur lebih besar dimiliki oleh kelas atas. Berikut ada kalimat yang ada dalam buku ajar PAI di SD berkaitan dengan bertamasya.

Herman memahami sahabatnya Zakaria yang tidak ikut piknik ke Taman Mini Indonesia Indah (TMII) karena ternyata Zakaria harus mengikuti ujian renang.

\section{Data 3}

PAI 6: halaman 79

Kutipan di atas sebagai penjelas materi berbaik sangka pada bab senangnya berakhlak terpuji, yang menjadi habitus kelas atas adalah piknik, mengapa dari sekian banyak contoh untuk dijadikan sebagai penjelas tentang berbaik sangka mengapa cerita piknik yang diangkat, padahal piknik merupakan habitus kelas atas dimana untuk melakukan piknik butuh biaya yang tidak sedikit, sehingga hanya kelas atas yang mudah melakukan piknik.

\section{B.2.4. Permainan modern}

Permainan kelas atas dengan permainan kelas bawah tentu terdapat perbedaan. Permainan yang dimainkan seseorang menunjukkan dari kalangan mana dia berasal. Permainan yang terdapat dalam buku pelajaran PAI di SD menunjukkan hal tersebut, permainan kelas atas lebih banyak dibandingkan dengan permainan kelas bawah. Dominasi ini membuat peserta didik dari kelas bawah canggung dan sulit memahami ketika belajar sesuatu yang jauh berbeda dari realitas yang biasanya dimainkan sehari - hari.

Begitu pula jika ada teman mengajak nonton televisi atau main video game terus menerus sehingga lupa makan dan belajar, kita harus menolaknya.

PAI 6: halaman 61

\section{Data 4}

\section{B.3. Habitus kelas terdominasi dalam teks buku ajar}

Sebagai kelas terdominasi, habitus kelas bawah juga disosialisasikan dalam buku pelajaran PAI di SD, akan tetapi porsinya sangat jauh lebih sedikit dibandingkan sosialisasi habitus kelas dominan yakni kelas atas. Selain itu, habitus kelas bawah sering digambarkan sebagai kelas dengan kebiasaan dan gaya hidup yang kurang baik, kotor, serta tidak patut ditiru. Habitus kelas bawah juga lebih banyak sebagai objek pelengkap kalimat daripada sebagai subjek. Habitus kelas bawah yang sebenarnya lebih dekat dengan realitas dan kehidupan nyata dari mayoritas peserta didik justru digambarkan sebagai sesuatu yang harus dijauhi. Apabila hal ini tidak segera disadari, maka beberapa habitus kelas bawah akan semakin hilang dari kehidupan masyarakat. Beberapa sosialisasi habitus kelas bawah dalam buku pelajaran PAI di SD di antaranya:

\section{B.3.1. Kebiasaan kelas bawah}

Sosialisasi habitus kelas bawah dilakukan dengan mencoba mengenalkan kebiasaan dari kelompok terdominasi ini. Beberapa kebiasaan kelas bawah yang ditampilkan melalui kalimat dalam buku pelajaran PAI di SD menunjukkan habitus kelas bawah. Kebiasaan itu merupakan sesuatu hal yang sering dilakukan oleh kelas bawah dan hampir tidak pernah dilakukan oleh kalangan kelas atas. Beberapa hal yang menjadi simbol kebiasaan kelas bawah yang terdapat dalam dalam buku pelajaran PAI di SD antara lain:

Kita ingin makan, harus membeli beras yang nantinya dimasak, atau membeli nasi dan lauk pauk di warung.

(PAI 6: halaman 25) 
Data 5

\section{B.3.2. Kehidupan yang sulit}

Salah satu sosialisasi habitus kelas bawah dalam buku ajar PAI di SD adalah dengan menggambarkan kehidupan kelas bawah yang sulit, dan pas-pasan, bahkan kekurangan. Bekerja dengan kemampuan seadanya yang masih memungkinkan untuk tetap menghasilkan uang. Kondisi yang serba kekurangan tentu saja bukan habitus kelas atas, kelas atas memiliki harta yang melimpah dan uang yang banyak, kehidupan kelas bawah ditampilkan dengan kondisi yang dekat dengan hidup yang susah dan kurang. Berikut beberapa kutipan penggambaran habitus kelas bawah.

Untuk hidup sehari-hari, Nenek Ipah mencari daun teratai dan kangkung di rawa-rawa yang tak jauh dari gubuknya. Pagi-pagi sekali, Nenek Ipah menuju rawa-rawa dengan harapan mendapat daun teratai dan kangkung yang banyak. Hasil daun teratai dijual ke pasar kepada tukang ikan basah. Daun teratai yang lebar dapat dijadikan sebagai pembungkus ikan basah

PAI 6: halaman 79

\section{Data 6}

\section{B.4. Dominasi kelas melalui gambar}

Sosialisasi habitus kelas melalui gambar ilustrasi dalam buku pelajaran PAI di SD ditunjukkan dengan dijadikannya beberapa gaya hidup, kebiasaan, ataupun beberapa kegiatan yang bias kelas. Sementara kebiasaan kelas bawah tidak banyak yang disajikan sebagai gambar ilustrasi dalam buku pelajaran PAI di SD. Dominasi habitus kelas atas tampak jelas terlihat dari hasil penelitian ini. Agar lebih jelas maka sosialisasi tersebut akan dijelaskan dengan analisis terhadap habitus kelas dominan dan kelas terdominasi yang disajikan dalam gambar ilustrasi.

\section{B.4.1. Sosialisasi habitus kelas dominan}

Habitus kelas selain ditampilkan dalam bahasa kalimat buku ajar, juga disosialisasikan melalui gambar. Gambar sebagai penjelas materi membuat peserta didik semakin tertarik untuk belajar dan membaca buku. Dalam setiap gambar memiliki makna yang berbeda tergantung dari sudut pandang apa gambar itu dilihat. Gambar juga menajdi salah satu media sosialisasi kelas yang berimbas pada terjadinya kekerasan simbolik oleh kelas dominan. Gambar ilustrasi dalam buku ajar PAI di SD yang menunjukkan bias kelas sosial berjumlah 91 gambar. Dari jumlah tersebut yang mensosialisasikan habitus kelas atas berjumlah 81 gambar atau sekitar $89 \%$, dan yang mensosialisasikan habitus kelas bawah sebanyak 10 gambar atau sekitar $11 \%$. Dari situ terlihat sekali betapa kelas atas mendominasi melalui gambar dalam buku ajar pai di SD.

Grafik 2: Dominasi Kelas Melalui Gambar

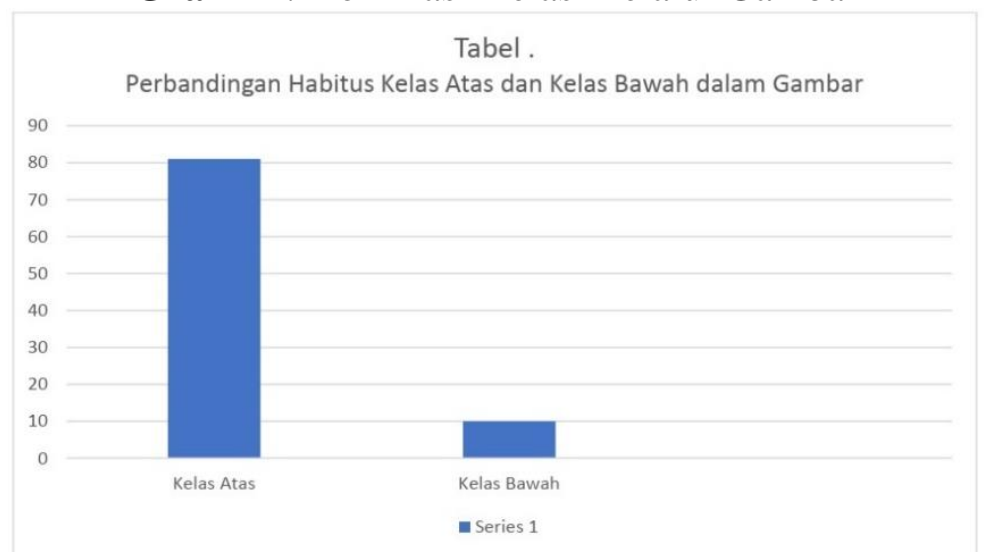


Dari grafik di atas dapat diketahui dengan jelas bagaimana besarnya dominasi habitus kelas atas terhadap habitus kelas bawah dalam tampilan gambar. Dominasi habitus kelas atas yang dilakukan melalui gambar sama halnya dengan sosialisasi melalui bahasa, sangat mendominasi. Besarnya dominasi tersebut menjadi ranah terjadinya kekerasan simbolik dalam buku ajar PAI di SD.

\section{B.4.2. Makan bersama}

Makan bersama menjadi salah satu sosialisasi habitus kelas atas dalam gambar ilustrasi di buku ajar, hal ini tidak berarti kelas bawah tidak pernah makan bersama, namun kebisaan seperti ini lebih banyak dilakukan oleh kelas atas. Untuk makan bersama dibutuhkan meja makan yang besar dan ruang makan yang luas, sedangkan kelas bawah hampir tidak memiliki ruang makan tersebut. Meja makan kelas bawah biasanya terdapat di dalam satu ruangan dengan dapur, itupun hanya tempat untuk menaruh makanan. Di dalam buku pelajaran PAI di SD, banyak ditemukan sosialisasi habitus kelas atas dengan mengenalkan kebiasaan makan bersama. Gambar ilustrasi yang menunjukkan habitus kelas atas tersebut antara lain:

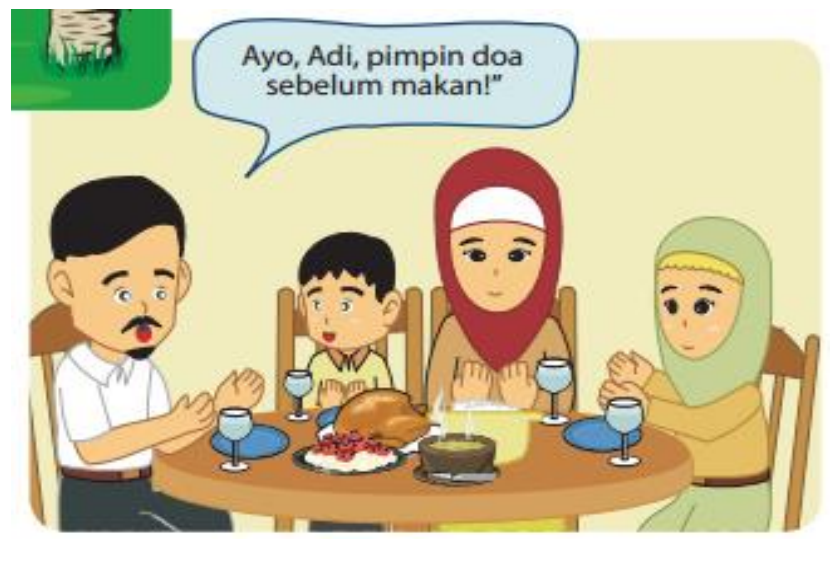

Data 7

Dalam kutipan gambar terlihat jelas bagaimana sebuah keluarga sedang menikmati makan bersama di meja makan, lengkap dengan hidangan yang nikmat dan lezat. Gambar 1 menunjukkan keluarga dari adi yang membiasakan berdoa sebelum makan, seharusnya untuk menjelaskan bagaimana adab berdoa sebelum makan tidak harus dengan gambar ilustrasi makan bersama dengan lauk yang lezat.

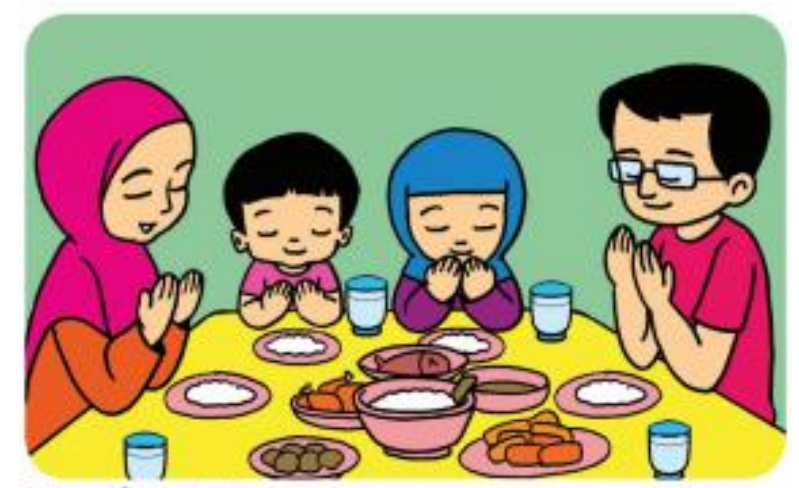

Gambar 5.3

Data 8

Gambar di atas merupakan latihan dari materi bersih dan sehat, sebagai lembar kerja siswa untuk mengamati dan menceritakan gambar tersebut, bagaimana bisa habitus kelas atas yang ditampilkan ,makan bersama dengan lauk yang lengkap, tentunya peserta didik dari 
kelas bawah merasa canggung karena gambar yang ditampilkan berbeda jauh dengan realitas mereka sehari-hari.

\section{B.5. Sosialisasi habitus kelas terdominasi \\ B.5.1. Pekerjaan kelas bawah}

Kegiatan ekonomi menjadi contoh jelas perbedaan kelas sosial, posisi dan jenis pekerjaan tentu saja dapat menunjukkan kelas sosial seseorang. Sosialisasi habitus kelas bawah dalam buku PAI di SD dapat dilihat dari pekerjaan kelas bawah diidentikkan dengan pekerjaan berat, pendapatan kecil, dan tidak memanfaatkan teknologi modern. Petani adalah contoh pekerjaan kelas bawah yang ditampilkan, sebagai negara agraris tentu saja bertani tidak bisa dipisahkan dari kehidupan masyarakat di Indonesia, namun jarang sekali petani di negeri ini yang hidupnya sejahtera, yang terjadi sebaliknya menderita karena permainan harga, ketika musim tanam harga bibit dan pupuk mahal, dan ketika panen harga jual hasil panen melorot .

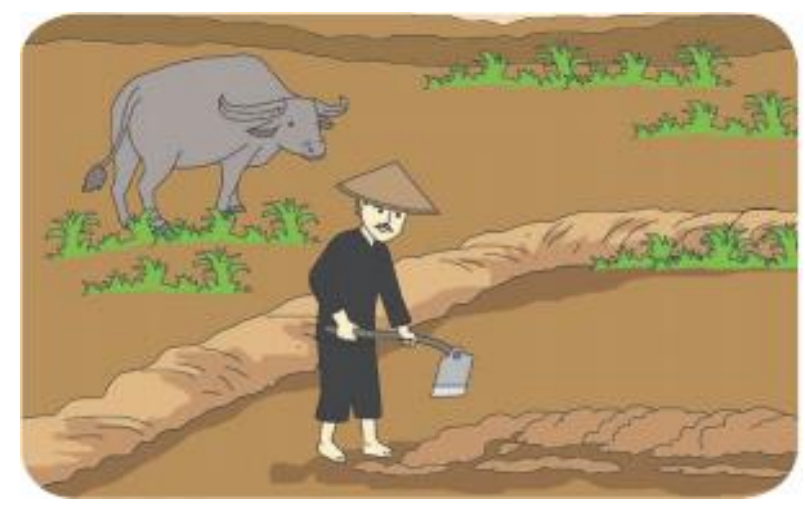

Data 9

Kutipan gambar di atas menunjukkan pekerjaan dari kelas bawah yang mana petani bekerja seharian di sawah, tapi mendapatkan hasil tidak seberapa, terkadang harus rela gagal panen karena hama ataupun penyebab yang lain, dibandingkan dengan kelas atas yang bisa mendapatkan uang banyak dengan pekerjaan yang relatif lebih mudah dan tidak hanya mengandalkan tenaga.

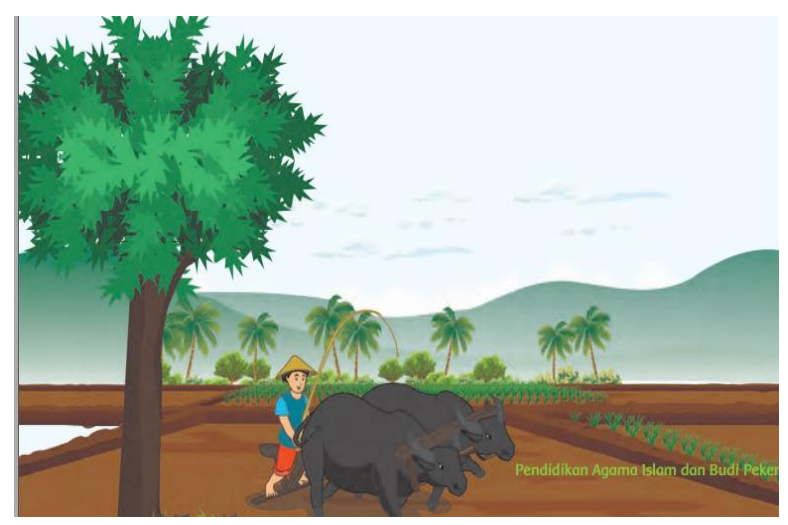

Data 10

Pada kutipan gambar ilustrasi di atas, menunjukkan habitus kelas bawah yang berkaitan dengan pekerjaan kelas bawah, seorang petani mengolah tanah di sawah menggunakan tenaga kerbau, padahal saat ini sudah jarang memakai tenaga hewan, karena sudah ada traktor yang lebih efisien untuk mengolah tanah. 


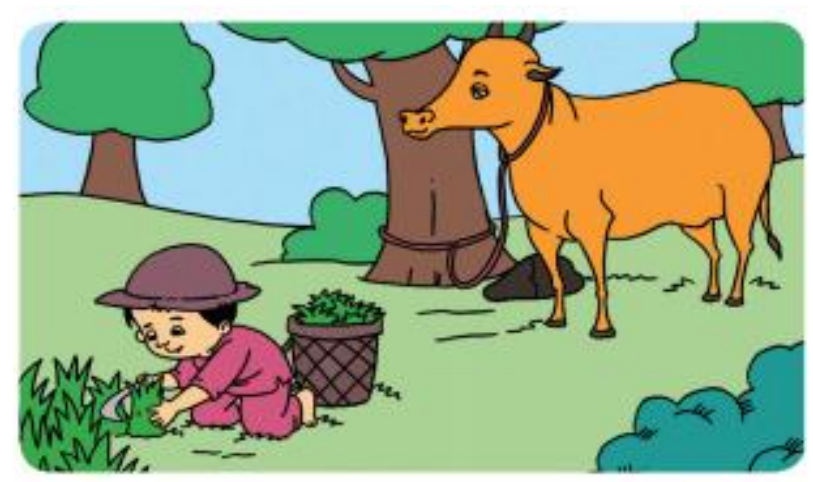

Data 11

Gambar di atas mengilustrasikan materi tentang kasih sayang, namun yang dijadikan gambar adalah habitus kelas bawah dimana anak mencari rumput untuk ternaknya, tentu saja anak kelas atas tidak pernah merasakan hal yang semacam ini, karena di rumah tugasnya hanya bermain dan belajar.

\section{B.5.2. Kebiasaan kelas bawah}

Kebiasaan dan kegiatan seseorang dapat menunjukkan dari kelas mana dia berasal, kebiasaan kelas atas tentu berbeda dengan kelas bawah. Kegiatan dan kebiasaan kelas bawah juga disosialisasikan di buku ajar PAI di SD namun porsi yang diberikan untuk habitus kelas bawah sangat sedikit dibanding kelas atas. Berikut beberapa habitus kelas bawah yang disosialisasikan di buku ajar PAI SD berkaitan dengan kebiasaan dan kegiatan sehari-hari.

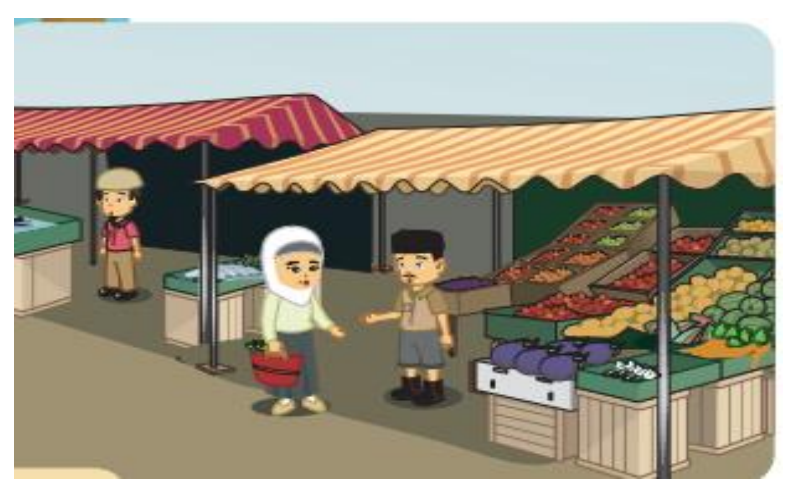

Kutipan gambar di atas menunjukkan habitus kelas bawah yang terbiasa belanja di pasar tradisional ataupun penjual pinggir jalan, berbeda dengan kelas atas yang memiliki habitus belanja di supermarket atau pusat perbelanjaan dengan uang yang banyak.

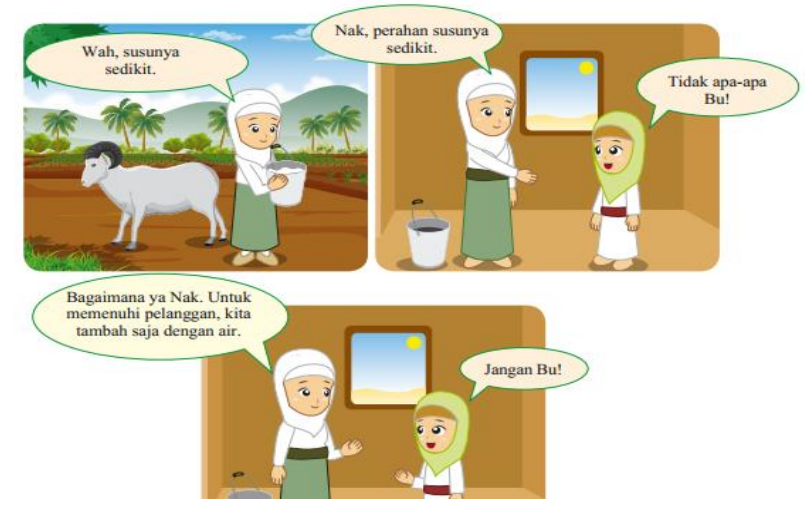




\section{Data 13}

Kutipan gambar di atas menunjukkan bagaimana realitas kelas bawah di mana seorang ibu penjual susu kambing yang hanya mendapatkan sedikit hasil perahan. Ilustrasi ini menjelaskan cerita pada zaman Khalifah Umar tentang materi berlaku jujur, padahal sebenarnya kelas atas juga banyak yang tidak jujur. Akan sangat relevan dan berkesan jika koruptor yang dijadikan contoh yang sehingga peserta didik akan menjauhi perbuatan tersebut.

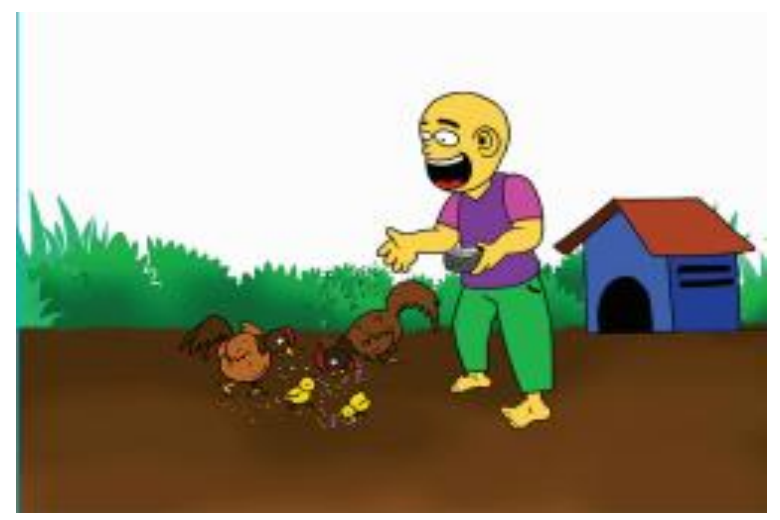

Data 14

Perbuatan terpuji pada hewan menjadi materi yang dijelaskan pada ilustrasi gambar, dimana itu merupakan habitus kelas bawah yang terbiasa memberi makan ternak ayam, dengan tidak memakai alas kaki. Tentu saja kelas atas tidak terbiasa seperti itu, bahkan hewan piaraannya hewan yang relatif mahal dan tertentu bukan seperti kelas bawah hewan yang ada di rumah merupakan hewan ternak sebagai tabungan jika ada keperluan mendadak.

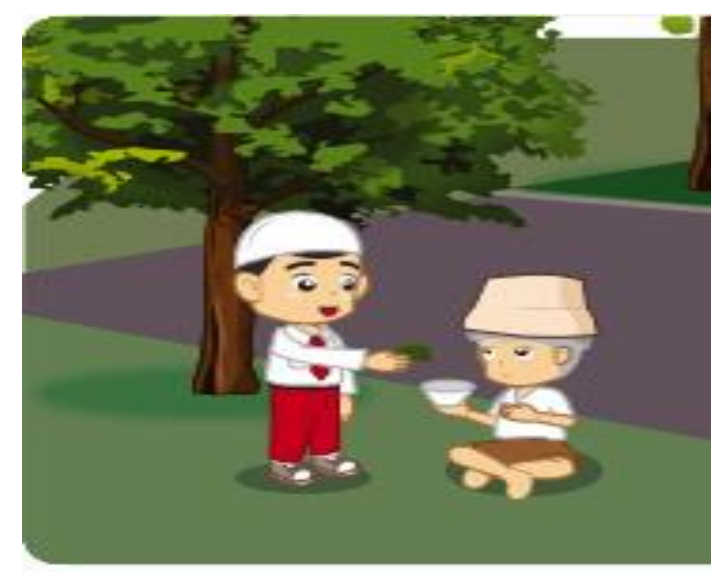

Data 15

Gambar di atas menjelaskan materi tentang bersedekah, tentu saja pengemis berasal dari kelas bawah sedangkan kelas atas sebagai pemberi sedekah. Pengemis di buku ajar PAI selalu dijadikan sebagai objek pelengkap seolah olah bersedekah hanya dengan uang, padahal kelas bawah juga bisa bersedekah dengan pikiran, tenaga, ataupun yang lainnya.

\section{B.5.3. Berangkat sekolah dengan jalan kaki}

Berangkat dan pulang sekolah adalah aktivitas setiap hari yang harus dilalui oleh anak sekolah, aktivitas ini penting karena ketika anak sampai di sekolah harus siap baik fisik maupun mental, ketika perjalanan berangkat sekolah terkendala maka aktivitas sekolah pun terganggu. Keberangkatan anak kelas atas tentu lebih aman dan terjamin karena mereka diantar menggunakan kendaraan yang nyaman dengan fasilitas sopir yang siap mengantar 
setiap hari, berbeda dengan kelas bawah yang harus jalan kaki. Berikut beberapa habitus kelas bawah yang ada di buku pelajaran PAI di SD berkaitan dengan aktivitas berangkat sekolah.

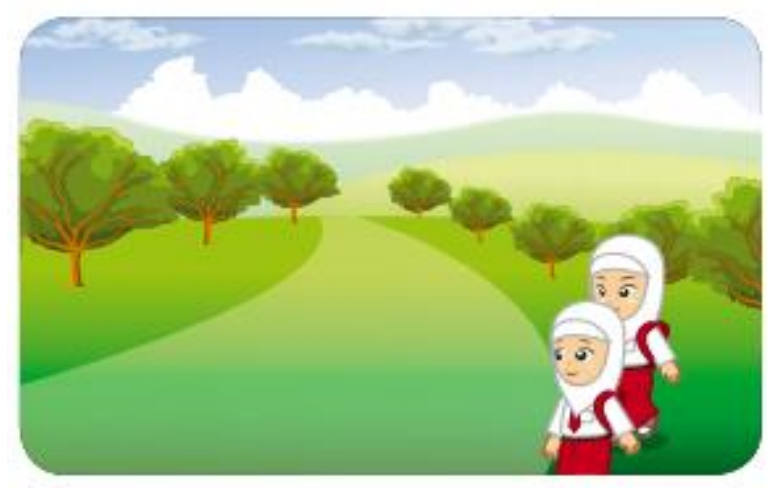

Data 16

Kutipan di atas menunjukkan habitus kelas bawah yang berangkat sekolah harus jalan kaki karena terlihat dari rute perjalanan yang dilalui. Kebiasaan kelas bawah yang hampir tidak pernah dilakukan oleh kelas atas adalah berangkat sekolah dengan berjalan kaki karena anak kelas atas biasanya diantar dengan kendaraan yang aman dan nyaman.

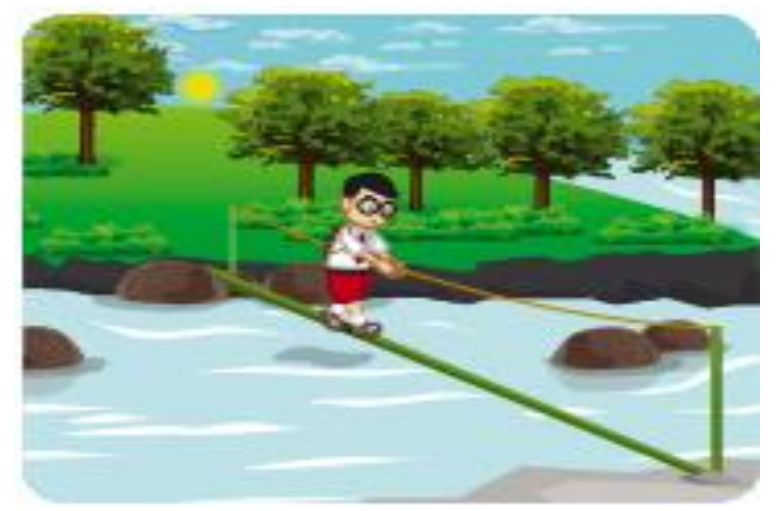

Data 17

Pada kutipan gambar terlihat bagaimana habitus kelas bawah yang harus menyeberang jembatan kayu untuk berangkat dan pergi ke sekolah, tentu saja kelas atas tidak merasakan bagaimana bahaya mengintai ketika harus melewati jembatan di sungai. Gambar menjelaskan materi tentang tidak putus asa.

Demikianlah habitus kelas atas dan habitus kelas bawah yang terdapat dalam buku pelajaran PAI di SD. Dominasi kelas atas terhadap kelas bawah yang ada merupakan tindakan kekerasan simbolik yang ada di lembaga pendidikan, yaitu SD. Mekanismenya dilakukan melalui buku pelajaran yang terjadi selama kegiatan belajar mengajar. Pembelajaran yang bertujuan meningkatkan kemampuan akademik dan mengubah sikap dan perilaku peserta didik agar berakhlakul karimah, ternyata ditumpangi kepentingan kelas atas untuk melanggengkan posisi dan status sosial dalam masyarakat.

\section{Penutup}

Kekerasan simbolik yang terjadi di SD berlangsung dalam kegiatan belajar mengajar antara pendidik dan peserta didik. Mekanisme yang berlangsung yaitu melalui strategi edukatif dengan menyembunyikan proses kekerasan simbolik dalam kurikulum atau yang biasa kita kenal dengan istilah hidden curriculum. Media yang dipakai untuk melanggengkan kekerasan ini salah satunya dengan buku pelajaran. Dalam buku pelajaran PAI di SD (SD), terdapat unsur dominasi kelas atas terhadap kelas bawah. Dominasi yang dimaksud 
berlangsung melalui sosialisasi habitus (gaya hidup, selera, persepsi, kebiasaan) kelas dalam buku pelajaran. Sosialisasi habitus dapat dilihat dari pemilihan bahasa ataupun kalimat serta penggunaan gambar ilustrasi merupakan alat komunikasi yang dapat menyampaikan informasi dan pesan yang ingin disampaikan. Begitu pula bahasa (kalimat) dan gambar ilustrasi yang terdapat dalam buku pelajaran, dapat menunjukkan habitus kelas sosial tertentu. Dengan memasukkannya ke dalam materi pelajaran, maka kekerasan simbolik berupa dominasi kelas bisa dipastikan para pendidik, peserta didik, maupun orang tua tidak menyadarinya. Sehingga kekerasan simbolik masih saja terus terjadi di lembaga pendidikan kita.

Dominasi kelas atas terhadap kelas bawah dapat dilihat dari kuantitas habitus yang disajikan dalam buku pelajaran. Hasil penelitian terhadap buku pelajaran PAI di SD ditemukan bahwa jumlah habitus kelas atas yang disajikan melalui kalimat dan gambar ilustrasi jauh lebih besar dibanding habitus kelas bawah. Jumlah bahasa (kalimat) dalam buku pelajaran yang mengandung bias kelas sebanyak 58 kalimat. habitus kelas atas yang dikenalkan sebanyak 41 kalimat (71\%), sedangkan kelas bawah hanya disajikan dalam 17 kalimat (29\%). Sementara sosialisasi habitus kelas melalui gambar ilustrasi sebanyak 91 gambar. Sebanyak 81 gambar (89\%) menunjukkan habitus kelas atas, sisanya yakni sejumlah 10 gambar $(11 \%)$ menunjukkan habitus kelas bawah. Apabila digabungkan, maka habitus kelas atas sebanyak 122 (82\%), dan habitus kelas bawah hanya 27 (18\%) dari total 149 kalimat dan gambar ilustrasi yang mengenalkan habitus kelas. Dari perbandingan sosialisasi kedua habitus, dominasi habitus kelas atas baik dalam kalimat maupun gambar terhadap kelas bawah sangat terlihat. Kelas atas sebagai kelas dominan dan kelas bawah sebagai kelas terdominasi sekaligus korban dari kekerasan simbolik. Dengan dominasi, kelas atas mencoba mempertahankan gaya hidup, selera, persepsi, maupun kebiasaan mereka serta mempengaruhi sikap dan persepsi kelas bawah untuk meniru dan mengikuti habitus kelas atas.

\section{DAFTAR PUSTAKA}

Affarah, I Wahyu Sulistya, dkk. Public Sharing on Prevention and Impact of Bullying in Adolescents. Prosiding PEPADU, e-ISSN: 2715-5811, Vol. 1, 2019.

Azra, Azyumardi. Paradigma Baru pendidikan Nasional Rekonstruksi dan Demokrasi. Jakarta: Kompas Media Nusantara, 2002.

Haryatmoko. Menyingkap Kepalsuan Budaya Penguasa. Majalah BASIS, Nomor 11- 12 Tahun Ke-52, November-Desember, 2003.

Krippendroff, Klaous. Content Analysis: Introduction to its Theory and Metodology, dalam Farid Wajidi, Analisis Isi, Pengantar Teori dan Metodologi, Jakarta: Rajawali, 1991.

Mukhopadhyay, Marmar. Peace Education Framework for Teacher Education. India: UNICEF, 2005.

Martono, Nanang. Kekerasan Simbolik di Sekolah Sebuah Ide Sosiologi Pendidikan Pierre Bourdieu, Depok: PT Rajagrafindo Persada, 2002.

Rusdiarti, Suna Riela. Bahasa, Pertarungan Simbolik dan Kekuasaan. Edisi Khusus Pieree Bourdie No. 11-12 tahun ke-52, 2003.

Sholikin, A. Pemikiran Politik Negara Dan Agama "Ahmad Syafii Maarif." Universitas Airlangga, 2013.

Solikhin, A. Islam, Negara, dan Perlindungan Hak-Hak Islam Minoritas. Journal of Governance, 1(1), 2016.

Sugiono. Metode Penelitian Pendidikan: Pendekatan Kualitatif Kuantitatif Dan R Dan D. Bandung: Alfabeta, 2006.

Ulfah. Kekerasan simbolik dalam wacana pembelajaran. Jurnal Pendidikan Insani, Vol 14, No.1, 2013. 